\title{
PENGARUH SIKAP DAN NORMA SUBJEKTIF TERHADAP NIAT BELI PRODUK SEPATU LEAGUE
}

\author{
I Kadek Alit Suarjana ${ }^{1}$ \\ Gede Suparna ${ }^{2}$ \\ ${ }^{1,2}$ Fakultas Ekonomi dan Bisnis Universitas Udayana (Unud), Bali, Indonesia \\ email: alitsuarjana16@gmail.com
}

\begin{abstract}
ABSTRAK
Tujuan penelitian ini adalah untuk mengetahui pengaruh sikap terhadap niat beli produk sepatu League di Kota Denpasar. Populasi penelitian ini adalah masyarakat yang memiliki keinginan membeli produk sepatu merek League di Kota Denpasar. Teknik pengambilan sampel dalam penelitian ini adalah purposive sampling yang didasari dengan kriteria bahwa responden memiliki keinginan untuk membeli produk sepatu merek League yang sudah memiliki pendapatan per bulan dan berdomisili di Kota Denpasar. Ukuran sampel dalam penelitian ini menggunakan parameter indikator, sehingga diperoleh jumlah sampel sebanyak 140 responden. Metode pengumpulan data menggunakan kuisioner. Teknik analisis yang digunakan adalah analisis regresi linier berganda. Hasil penelitian ini menunjukkan bahwa sikap dan norma subjektif berpengaruh positif dan signifikan terhadap niat beli produk sepatu League di kota Denpasar. Hal ini memiliki makna bahwa semakin positif sikap konsumen pada produk sepatu League dan semakin baik norma subjektif pada produk tersebut, maka semakin tinggi niat beli konsumen pada produk sepatu League di Kota Denpasar.

Kata Kunci: sikap, norma subjektif, niat beli
\end{abstract}

\section{ABSTRACT}

The purpose of this study was to determine the effect of attitudes towards the purchase intention of League shoes products in Denpasar City. The population of this study is the people who have the desire to buy League brand shoes products in Denpasar City. The sampling technique in this study was purposive sampling which was based on the criteria that respondents had the desire to buy League brand shoes products that already had monthly income and were domiciled in Denpasar City. The sample size in this study uses indicator parameters, so that the number of samples obtained is 140 respondents. Methods of collecting data using questionnaires. The analysis technique used is multiple linear regression analysis. The results of this study indicate that subjective attitudes and norms have a positive and significant effect on the purchase intention of League shoes products in the city of Denpasar. This means that the more positive the consumer attitude towards League shoes products and the better the subjective norms on these products, the higher consumer purchase intention in League shoes products in Denpasar City.

Keywords: attitude, subjective norms, purchase intention 


\section{PENDAHULUAN}

Olahraga merupakan aktifitas yang semakin diminati oleh masyarakat modern saat ini, selain untuk sekedar menjalankan hobi olahraga dapat membuat tubuh lebih sehat dan mengurangi resiko penyakit. Seseorang dalam berolahraga tidak lepas dari sepatu olahraga untuk menunjang kegiatan olahraganya. Ada beberapa merek sepatu olahraga yang sangat populer dipasaran yang selalu bersaing untuk merebut minat konsumen agar membeli produk mereka (Nurdiansyah, 2017). Berdasarkan Asosiasi Persepatuan Indonesia (Aprisindo) yang di kutip dari Industri.bisnis.com menyatakan bahwa terdapat beberapa merek sepatu dengan brand lokal yang mampu merajai pasar alas kaki di dalam negeri (Silitonga, 2018). Data mengenai merek sepatu sekolah remaja yang sukses meraih pangsa pasar terbesar di dalam negeri pada 2017 menurut Asosiasi Persepatuan Indonesia (Aprisindo) dapat dilihat pada Tabel 1.

\section{Tabel 1.}

Merek Sepatu Sekolah Remaja yang Sukses Meraih Pangsa Pasar Terbesar di Dalam Negeri pada 2017

\begin{tabular}{|c|c|c|}
\hline No & Merek & Pangsa Pasar \\
\hline 1 & Converse & $3,5 \%$ \\
\hline 2 & Nike & $6,0 \%$ \\
\hline 3 & Bata & $4,1 \%$ \\
\hline 4 & Tomkins & $3,8 \%$ \\
\hline 5 & League & $3,2 \%$ \\
\hline 6 & North Star & $2,8 \%$ \\
\hline
\end{tabular}

Data dalam Tabel 1. menunjukkan bahwa Sepatu League yang merupakan brand lokal Indonesia masuk ke dalam 5 besar merek sepatu sekolah remaja yang sukses meraih pangsa pasar terbesar di dalam negeri pada tahun 2017. Namun, League hanya mampu menguasai $3,2 \%$ pangsa pasar di Indonesia. Informasi tersebut memberikan informasi bahwa sepatu lokal belum mampu memimpin pangsa pasar sepatu di Indonesia, karena masih kalah saing dengan merek internasional, sehingga produsen sepatu lokal perlu mengakomodasi selera pasar, varian produk yang luas disertasi dengan ciri khas masing-masing agar mampu bersaing secara ketat dengan merek sepatu internasional. Perusahaan harus mengerahkan segala upaya dalam memenuhi kebutuhan dan keinginan konsumen. Jadi apabila perusahaan mampu memenuhi kebutuhan dan keinginan konsumen maka akan tercipta hubungan yang harmonis antara perusahaan dengan konsumen (Pradnyana \& Sukawati, 2016).

League merupakan brand lokal yang khusus memproduksi berbagai produk penunjang olahraga yang memiliki kualitas internasional, salah satu produk unggulannya adalah sepatu olah raga. League selalu melakukan inovasi agar produknya terlihat lebih unggul dari pada produk kompetitor. League sebagai perusaahaan sepatu, apparel, dan aksesori olahraga terus berusaha meningkatkan performa perusahaan untuk bisa memenangkan pasar global. Selama 20 tahun, League telah memproduksi produk dan mengekspor ke mancanegara dengan mencantumkan merek internasional, seperti Nike. Sejak tahun 2004, League mulai membangun merek Indonesia ke pasar global. Produk yang dihasilkan dari 
pabrik di Indonesia kemudian diekspor ke berbagai negara. Distribusi produk League di Indonesia adalah sebesar 60 persen. Produk League tersebut didistribusikan melalui toko-toko olahraga di daerah dan melalui Matahari Departmen Store yang memiliki gerai yang tersebar di seluruh Indonesia, sehingga membuat produk League dengan mudah ditemui konsumen. Strategi produsen League tersebut yang bertujuan agar produk League dengan mudah ditemui konsumen pada nyatanya belum mampu meningkatkan minat beli konsumen di Indonesia. Rendahnya minat beli konsumen pada sepatu merek League ini juga terjadi di Bali.

Berdasarkan hasil Pra Survei yang dilakukan terhadap data penjualan merek sepatu sekolah Remaja di Matahari Departmen Store Denpasar dan toko-toko olahraga populer di Kota Denpasar, menunjukkan bahwa produk sepatu League masih kalah saing dengan merek lainnya. Data penjualan sepatu sekolah remaja per tahun 2017 di Kota Denpasar dapat dilihat pada Tabel 2.

Tabel 2.

Data Penjualan Sepatu Sekolah Remaja Tahun 2018 di Denpasar

\begin{tabular}{ccccccc}
\hline \multirow{2}{*}{ MEREK } & \multicolumn{3}{c}{ Toko Sepatu Olahraga Populer di Kota Denpasar } & \\
\cline { 2 - 5 } & $\begin{array}{c}\text { Istana } \\
\text { Sport }\end{array}$ & $\begin{array}{c}\text { Hawaii } \\
\text { Sport }\end{array}$ & $\begin{array}{c}\text { Arena } \\
\text { Sport }\end{array}$ & $\begin{array}{c}\text { Sport } \\
\text { Station }\end{array}$ & $\begin{array}{c}\text { Matahari } \\
\text { Dep. Store }\end{array}$ & Jumlah \\
\hline Nike & 1602 & 1672 & 1594 & 1978 & 2168 & 9014 \\
Specs & 1480 & 1260 & 1603 & 2097 & 2165 & 8605 \\
Adidas & 1061 & 1356 & 1172 & 1536 & 1527 & 6652 \\
Reebok & 678 & 428 & 598 & 984 & 1362 & 4050 \\
League & 235 & 979 & 462 & 761 & 837 & 3274 \\
\hline Sumber $:$ survey pada Bagian Penjualan Toko, 2018
\end{tabular}

Sumber : survey pada Bagian Penjualan Toko, 2018

Tabel 2. menunjukkan bahwa terdapat banyaknya pesaing produk sepatu olahraga di Kota Denpasar. Tingginya persaingan yang dihadapi oleh produsen produk sepatu tersebut mempengaruhi niat beli konsumen untuk melakukan pembelian produk sepatu olahraga di Kota Denpasar, sehingga sangat penting untuk mengetahui kebutuhan dan keinginan konsumen sebelum mengeluarkan produk. Salah satu cara untuk mengetahui kebutuhan dan keinginan konsumen adalah dengan mempelajari hal-hal yang berhubungan dengan perilaku konsumen, yaitu sikap dan norma subyektif. Sikap konsumen adalah ekspresi perasaan yang menunjukkan apakah seseorang menyenangi ataupun tidak menyenangi, menyukai atau tidak menyukai dan menyetujui maupun tidak menyetujui suatu obyek (Simamora, 2015:152). Sedangkan norma subyektif merupakan persepsi seseorang terhadap pendapat orang lain yang mempengaruhi niat untuk melaksanakan atau tidak melaksanakan perilaku (Mada, 2016).

Menurut Ajzen dan Fishbein mengatakan Theory of Reasoned Action perilaku seseorang merupakan realisasi dari kemauan atau niat seseorang untuk berperilaku (Ajzen, 2008). Faktor-faktor yang membentuk niat seperti sikap pada atribut produk dan norma subyektif menyangkut pendapat seseorang, apakah referen akan mempengaruhi perilakunya (Sigit, 2006). Model tindakan beralasan merupakan serangkaian komponen sikap yang saling berhubungan. Keyakinan menyebabkan terjadinya sikap, dan keyakinan normatif menyebabkan norma 
subyektif. Sikap dan norma subyektif menyebabkan niat dan niat menyebabkan perilaku aktual.

Azwar (2012:45) menyatakan bahwa dalam interaksi sosialnya, individu beraksi membentuk pola sikap tertentu terhadap suatu objek. Diantara berbagai faktor yang mempengaruhi pembentukan sikap adalah pengalaman pribadi, kebudayaan, orng lain yang dianggap penting, media massa, institusi atau lembaga pendidikan dan lembaga agama, serta faktor dalam diri individu. Niat seseorang dalam membeli produk/jasa merupakan hal yang dipengaruhi oleh sikap seseorang terhadap perilaku pembelian serta norma subjektif. Hal tersebut sejalan dengan pendapat Ajzen (2008) yang mengatakan bahwa niat berperilaku itu dapat diketahui dengan memperkirakan sikap terhadap perilaku dan norma subjektif, dimana tindakan seseorang adalah realisasi dari keinginan atau niat seseorang untuk bertindak (Sigit, 2006).

Niat beli merupakan penilaian subyektif tentang apa yang akan dimiliki oleh konsumen di masa yang akan datang terhadap produk (Hartini, 2012), dimana niat beli merupakan evaluasi dan sikap konsumen terhadap produk dengan melihat faktor eksternal sehingga berdampak pada kesediaan konsumen untuk membeli produk atau jasa pada merek tertentu (Wen \& Li, 2013). Niat beli begitu penting karena nantinya akan terkait dengan proses pembelian, di mana menurut Kotler \& Armstrong (2008:179) terdapat lima tahap proses pembelian, yaitu pengenalan kebutuhan, pencarian informasi, evaluasi alternatif, keputusan pembelian dan perilaku setelah pembelian.

Faktor-faktor yang mempengaruhi niat beli adalah dapat diperkirakan yaitu sikap pada tindakan dan norma subyektif menyangkut persepsi seseorang, apakah orang lain yang dianggap penting akan mempengaruhi perilakunya. Anidia (2016) dalam penelitiannya mendefinisikan sikap sebagai reaksi atau perasaan terhadap sebuah rangsangan. Penggunaan kata sikap yang mengacu pada afeksi atau reaksi evaluatif umum merupakan hal yang biasa di antara para peneliti perilaku konsumen saat ini.

Norma subjektif merupakan keyakinan individu mengenai harapan orangorang sekitar yang berpengaruh (significant other) baik perorangan ataupun perkelompok untuk menampilkan perilaku tertentu atau tidak. Pengertian diatas menjelaskan bahwa norma subjektif adalah produk dari persepsi individu tentang beliefs yang dimiliki orang lain. Significant other memberikan panduan tentang hal yang tepat untuk melakukannya. Sedangkan Ajzen (2008) menjelaskan bahwa norma subyektif adalah perasaan atau pendugaan seseorang terhadap harapanharapan dari orang-orang yang ada dalam kehidupannya mengenai dilakukan atau tidak dilakukan perilaku tertentu. Sejalan dengan itu Paul \& Olson (2000:150) mengatakan bahwa norma subjektif atau sosial mencerminkan persepsi konsumen tentang apa yang mereka anggap bahwa orang lain agar mereka lakukan. Norma subjektif mencerminkan persepsi konsumen tentang apa yang mereka anggap bahwa orang lain ingin agar mereka melakukan perilaku khusus.

Keyakinan normatif utama konsumen sehubungan dengan melakukan apa yang orang lain ingin mereka lakukan dan motivasi untuk memenuhi harapan orang lain tersebut dikomuninasikan untuk membentuk norma subjektif. Norma subjektif memiliki dua komponen yaitu keyakinan normatif dan motivasi. 
Mengukur keyakinan normatif sama dengan mengukur pernyataan tentang keyakinan, dan motivasi untuk mengikutinya seperti sebuah peringkat yang penting. Jadi bagi setiap orang atau kelompok referensi, peringkat ini digandakan, dan hasilnya ditambahkan pada setiap orang kelompok referen yang dipertimbangkan (Mowen \& Minor, 2007:340). Referen merupakan kelompok di sekitar konsumen (orang lain penting) dimana ketika konsumen mengidentifikasikan dirinya dengan kelompok tersebut, sehingga konsumen mengambil banyak nilai, sikap, atau perilaku para anggota kelompok. Karena itu referen dapat berupa anggota keluarga, teman, sahabat, atasan, bawahan, dan seorang ahli.

Marhaini (2008) mengatakan bahwa perilaku seseorang tergantung niat, kemudian niat dalam berperilaku tergantung dari sikap (attitude) dan norma subyektif. Di sisi lain, keyakinan terhadap perilaku dan evaluasi akan menentukan perilaku. Keyakinan normatif dan motivasi untuk mengikuti pendapat orang lain akan menentukan norma subyektif. Menurut Sumarwan (2011:58) perilaku konsumen adalah kegiatan individu yang secara langsung terlibat dalam mendapatkan dan mempergunakan barang dan jasa, termasuk didalamnya proses pengambilan keputusan pada persiapan dan penentuan kegiatan-kegiatan. Penelitian oleh Moon et al. (2015) diperoleh bahwa sikap dan norma subyektif memberikan efek positif terhadap niat pembelian.

Terdapat lima tahap proses pembelian yang dilakukan konsumen yaitu: Pengenalan masalah, proses pembelian dimulai dengan pengenalan masalah. Pembeli menyadari adanya perbedaan antara keadaan yang sebenarnya dan keadaan yang diinginkan. Kebutuhan dapat digerakkan oleh rangsangan dari dalam diri atau dari luar pembeli. Para pemasar perlu mengenal berbagai hal yang dapat menggerakkan kebutuhan atau minat tertentu konsumen. Pencarian informasi, hal yang penting bagi seorang pemasar adalah mengetahui sumbersumber informasi pokok yang akan diperhatikan konsumen dan pengaruh relatif setiap informasi terhadap rangkaian keputusan membeli. Sumber-sumber informasi konsumen terbagi menjadi empat kelompok, yaitu: sumber pribadi yang meliputi keluarga, teman, tetangga, kenalan; sumber niaga yang meliputi iklan, petugas penjualan, penjual, pameran; sumber umum yang meliputi media massa, organisasi konsumen; dan sumber pengalaman yang meliputi pernah menangani dan menguji.

Penilain alternatif, ada beberapa konsep dasar tertentu yang membantu memperjelas proses penilaian konsumen. Pertama adalah sifat-sifat produk, kedua konsumen mungkin mengkaitkan bobot dari pentingnya ciri-ciri yang berbeda dengan ciri-ciri yang sesuai, ketiga adalah konsumen mungkin mengembangkan seperangkat kepercayaan merek dimana setiap merek menonjolkan setiap ciri, keempat konsumen dianggap memiliki sebuah fungsi kemanfaatan untuk setiap ciri, dan kelima berkaitan dengan sikap konsumen terhadap beberapa pilihan merek terbentuk melalui prosedur penilaian.

Keputusan membeli, pada tahap ini menyebabkan konsumen membentuk pilihan diantara beberapa merek yang tergabung dalam perangkat pilihan. Konsumen mungkin juga membentuk maksud untuk membeli dan cenderung membeli merek yang disukainya. Namun demikian dua faktor lain yang dapat 
mencampuri maksud membeli dengan keputusan membeli, yaitu pertama sikap orang lain, dan kedua adalah faktor situasi yang tidak terduga mungkin muncul dan mengubah maksud pembelian. Perilaku setelah pembelian, setelah membeli produk konsumen akan mengalami beberapa tingkat kepuasan atau ketidakpuasan. Konsumen juga akan melakukan beberapa kegiatan setelah membeli produk yang akan menarik bagi pemasar. Tugas para pemasar belum selesai setelah produk dibeli oleh konsumen, namun akan terus berlangsung hingga periode waktu setelah pembelian.

Pernyataan ini dipertegas oleh hasil penelitian Chekima et al. (2015) yang menemukan bahwa secara simultan sikap dan norma subyektif mengarahkan dampak positif terbesar pada niat pelanggan untuk membeli produk. Penelitian Pradipta \& Suprapti (2013) menunjukkan bahwa sikap dan norma subyektif berpengaruh positif signifikan terhadap niat memilih, di mana norma subyektif berpengaruh lebih kuat dari pada sikap pemilih. Hal ini mengindikasikan pengaruh eksternal (lingkungan sosial) lebih kuat dari faktor internal. Penelitian Crespo \& Rodríguez (2010) diperoleh bahwa sikap terhadap e-commerce dan subjektif merupakan faktor utama yang mempengaruhi keputusan untuk membeli produk. Sedangkan penelitian Laili (2010) menemukan bahwa sikap konsumen tidak berpengaruh terhadap niat beli.

Berdasarkan fenomena yang telah dipaparkan, kemudian terdapat ketidakkonsistenan hasil penelitian terdahulu, maka tujuan penelitian ini adalah untuk mengetahui pengaruh sikap dan norma subyektif terhadap niat beli produk sepatu League di kota Denpasar. Penelitan yang dilakukan oleh Pradnyana \& Sukawati (2016); Sigit (2006); Eriyani \& Wiyono (2012) menemukan bahwa bahwa terdapat pengaruh positif signifikan antara sikap terhadap niat beli.

Mandasari \& Nurcaya (2013) menyatakan bahwa sikap konsumen berpengaruh signifkan terhadap niat membeli. Pradipta \& Suprapti (2013) menyatakan bahwa peran sikap dan norma subyektif akan menentukan niat berperilaku dan akhirnya menentukan perilaku. Marhaini (2008) dalam penelitiannya menemukan bahwa secara parsial maupun simultan sikap konsumen dan norma subyektif konsumen memiliki pengaruh signifikan terhadap minat berperilaku konsumen. Oleh karena itu, untuk mengkonfirmasi hubungan antara sikap terhadap niat beli, maka diajukan hipotesis sebagai berikut:

$\mathrm{H}_{1}$ : Sikap berpengaruh positif dan signifikan terhadap niat beli

Suprapti (2010) menyatakan bahwa norma subyektif yang diterapkan mampu memberikan dampak positif dan signifikan dalam niat membeli. Ini pun diungkapkan Sigit (2006) menemukan bahwa norma subyektif berpengaruh positif terhadap niat beli. Norma Subyektif secara parsial berpengaruh signifikan terhadap niat membeli. Mandasari \& Nurcaya (2013) menyebutkan bahwa norma subyektif berpengaruh positif dan signifikan terhadap niat beli. Oleh karena itu, untuk mengkonfirmasi hubungan antaranorma subyektif terhadap niat beli, maka diajukan hipotesis sebagai berikut:

$\mathrm{H}_{2}$ : Norma subyektif berpengaruh positif dan signifikan terhadap niat beli

Berdasarkan kajian penelitian terdahulu dan hipotesis yang sudah dirumuskan, maka model konseptual dalam penelitian ini adalah sebagai berikut: 


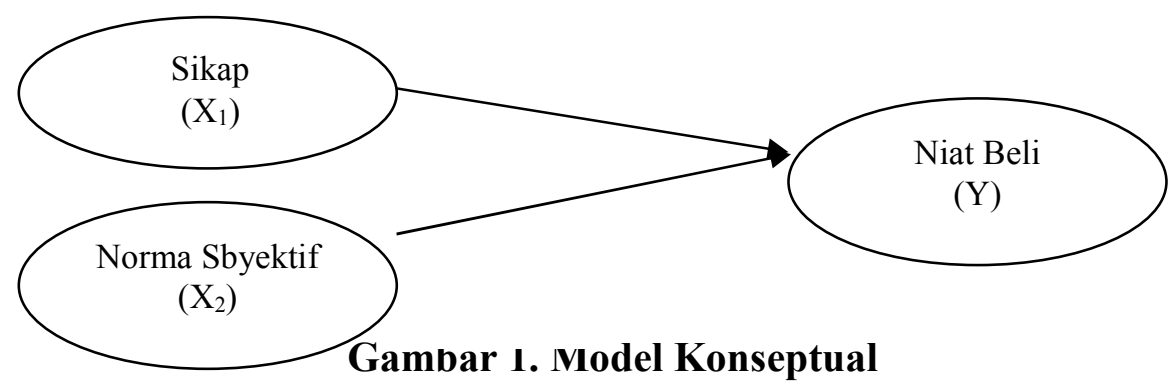

Sumber : kajian penelitian terdahulu

\section{METODE PENELITIAN}

Penelitian ini digolongkan sebagai penelitian asosiatif (hubungan), yaitu penelitian yang bertujuan untuk mengetahui hubungan dari dua variabel atau lebih (Sugiyono, 2013:5). Metode ini digunakan untuk mengetahui pengaruh sikap dan norma subyektif terhadap niat beli. Penelitian ini dilakukan di Kota Denpasar, Bali. Dasar dari pemilihan lokasi ini sebagai lokasi penelitian adalah karena kota Denpasar merupakan Ibu Kota Provinsi Bali sekaligus memiliki jumlah penduduk terbanyak di Provinsi Bali, selain itu kota Denpasar dipilih sebagai lokasi penelitian karena belum ada penelitian mengenai pengaruh sikap dan norma subyektif terhadap niat beli dengan menggunakan subjek pembelian sepatu merek League. Adapun subjek dalam penelitian ini adalah responden yang berdomisili di Kota Denpasar. Sebagai obyek dalam penelitian adalah sikap, norma subyektif dan niat beli. Variabel yang digunakan dalam penelitian ini antara lain variabel bebas dan variabel terikat yang secara rinci dirangkum dalam Tabel 3.

Populasi dalam penelitian ini adalah masyarakat yang memiliki keinginan membeli produk sepatu merek League di Kota Denpasar, yang tidak diketahui jumlahnya. Sampel dalam penelitian ini adalah konsumen yang memenuhi kriteria tertentu yang sesuai dengan penelitian niat beli konsumen terhadap produk sepatu League di Kota Denpasar. Sampel diambil menggunakan metode non probability sampling, yaitu teknik yang tidak memberi peluang atau kesempatan sama bagi setiap unsur atau anggota populasi untuk dipilih menjadi sampel. Teknik pemilihan sampel menggunakan teknik purposive sampling, yaitu teknik penentuan sampel berdasarkan pertimbangan maupun syarat - syarat tertentu.

Pertimbangan yang digunakan dalam pengambilan sampel yaitu responden telah menyelesaikan pendidikan SMA. Pertimbangan ini digunakan dengan alasan responden sudah dapat memahami isi dari kuesioner dan memiliki pemahaman yang lebih luas. Kemudian responden memiliki keinginan untuk membeli produk sepatu merek League, berdomisili di Kota Denpasar dan memiliki pendapatan perbulan, dimana pendapatan tersebut bisa berasal dari gaji maupun bekal yang diberikan orang tua dalam satu bulan.

Sugiyono (2013:56) mengemukakan ukuran sampel yang baik minimal 5 sampai dengan 10 kali dari jumlah variabel yang diteliti. Penelitian ini menggunakan 14 indikator, maka berdasarkan aturan tersebut diperoleh ukuran sampel sebesar 70 - 140 responden. Dalam penelitian ini ukuran sampel yang digunakan adalah sebesar 140 responden. Data yang dikumpulkan dalam penelitian ini menggunakan metode kuisioner. Kuisioner merupakan daftar 
pertanyaan terstruktur yang telah dipersiapkan sebelumnya dan diberikan kepada responden yang telah dipilih dan dipergunakan untuk memperoleh data konsumen atau responden. Melalui kuisioner maka akan diperoleh informasi yang relevan dengan tujuan survey dan dapat memperoleh informasi seakurat mungkin. Skala pengukuran yang digunakan adalah Skala Likert 5 point.

Tabel 3.

Rangkuman Variabel dan Indikator Penelitian

\begin{tabular}{|c|c|c|c|}
\hline No & Variabel & Indikator & Sumber \\
\hline 1. & $\begin{array}{l}\text { Niat Beli } \\
\qquad(Y)\end{array}$ & $\begin{array}{l}\text { 1. Minat eksploratif } \\
\text { 2. Minat referensial } \\
\text { 3. Minat preferensial } \\
\text { 4. Minat transaksional }\end{array}$ & Ferdinand (2006) \\
\hline 2. & $\begin{array}{l}\text { Sikap } \\
\left(\mathrm{X}_{1}\right)\end{array}$ & $\begin{array}{l}\text { 1. Memilih produk karena merupakan brand yang } \\
\text { terkenal } \\
\text { 2. Harga produk terjangkau. } \\
\text { 3. Desain produk elegan dan mewah. } \\
\text { 4. Produk memiliki kualitas yang baik. } \\
\text { 5. Produk memiliki banyak pilihan warna }\end{array}$ & $\begin{array}{l}\text { James \& Christodoulidou } \\
\text { (2011) }\end{array}$ \\
\hline 3. & $\begin{array}{l}\text { Norma . } \\
\text { Subjektif } \\
\quad\left(\mathrm{X}_{2}\right)\end{array}$ & $\begin{array}{l}\text { 1. Anggota keluarga menyetujui pembelian produk } \\
\text { 2. Menuruti pendapat teman dekat/sahabat dalam } \\
\text { hal pembelian produk } \\
\text { 3. Teman dan kerabat memberi tanggapan yang } \\
\text { baik pada produk. } \\
\text { 4. Teman dan kerabat menganjurkan untuk } \\
\text { membeli produk } \\
\text { 5. Teman dan kerabat menggunakan produk }\end{array}$ & Anidia (2016) \\
\hline
\end{tabular}

Sumber: Kajian penelitian sebelumnya, 2018

Data jawaban kuisioner yang sudah terkumpul selanjutnya di analisis dengan uji instrumen yang terdiri dari uji validitas dan uji reliabilitas. Sebuah instrumen dikatakan valid jika mampu mengukur apa yang seharusnya diukur, dan dapat mengungkap data dari variabel yang diteliti secara tepat. Syarat minimum untuk dianggap memenuhi syarat adalah kalau $r \geq 0,3$. Jadi kalau korelasi antara butir skor dengan skor total kurang dari 0,3 maka butir dalam instrumen tersebut dinyatakan tidak valid. Sedangkan, uji reliabilitas bertujuan untuk mencari tahu sejauh mana kosistensi alat ukur yang digunakan, sehingga bila alat ukur tesebut digunakan kembali untuk meneliti obyek yang sama dan dengan teknik yang sama pula walaupun waktunya berbeda, maka hasil yang akan diperoleh adalah sama.

Data yang dikumpulkan dalam penelitian ini akan dianalisis dengan cara regresi linier berganda, untuk mengetahui ketergantungan suatu variabel terikat dengan satu atau lebih variabel bebas. Analisis ini juga dapat menduga arah dari hubungan tersebut serta mengukur derajat keeratan hubungan antara satu variabel terikat dengan satu variabel bebas (Umar, 2013:93). Dalam analisis, peneliti dibantu dengan program computer Statitical Pacage of Social Science (SPSS) versi 15.0 for Windows, dengan persamaan regresi sebagai berikut:

$$
\mathrm{Y}=\alpha+\beta_{1} X_{1}+\beta_{2} X_{2}+\mu i
$$

Dimana :

$$
\mathrm{Y} \quad=\text { Niat Beli }
$$




$$
\begin{aligned}
X_{1}= & \text { Sikap } \\
X_{2}= & \text { Norma subyektif } \\
\alpha= & \text { Konstanta } \\
\beta_{1-} \beta_{2}= & \text { Koefisien regresi dari } \mathrm{X}_{1}-\mathrm{X}_{2} \\
\mu i \mathrm{i}= & \text { Variabel pengganggu (residual error) yang mewakili faktor lain } \\
& \text { berpengaruh terhadap Y namun tidak dimasukkan dalam model. }
\end{aligned}
$$

Karena dalam penelitian ini menggunakan statistik parametrik dengan model regresi berganda, maka sebelumnya perlu dilakukan uji asumsi klasik yang meliputi uji normalitas, uji multikolinieritas, dan uji heteroskedastisitas.

\section{HASIL DAN PEMBAHASAN}

Penelitian ini dilakukan untuk mengetahui pengaruh sikap dan norma subjektif terhadap niat beli produk sepatu League pada masyarakat di kota Denpasar. Pengumpulan data dilakukan melalui penyebaran kuesioner kepada 140 orang responden. Penyebaran kuesioner hingga semua kuesioner terjawab dan terkumpul kembali pada peneliti menghabiskan waktu 15 hari yaitu mulai tanggal 13 Agustus sampai 27 Agustus. Distribusi kuesioner beserta tingkat pengembalian kuesioner yang dapat diolah disajikan dalam Tabel 4. sebagai berkut:

\section{Tabel 4.}

Rincian Pengiriman dan Pengembalian Kuesioner

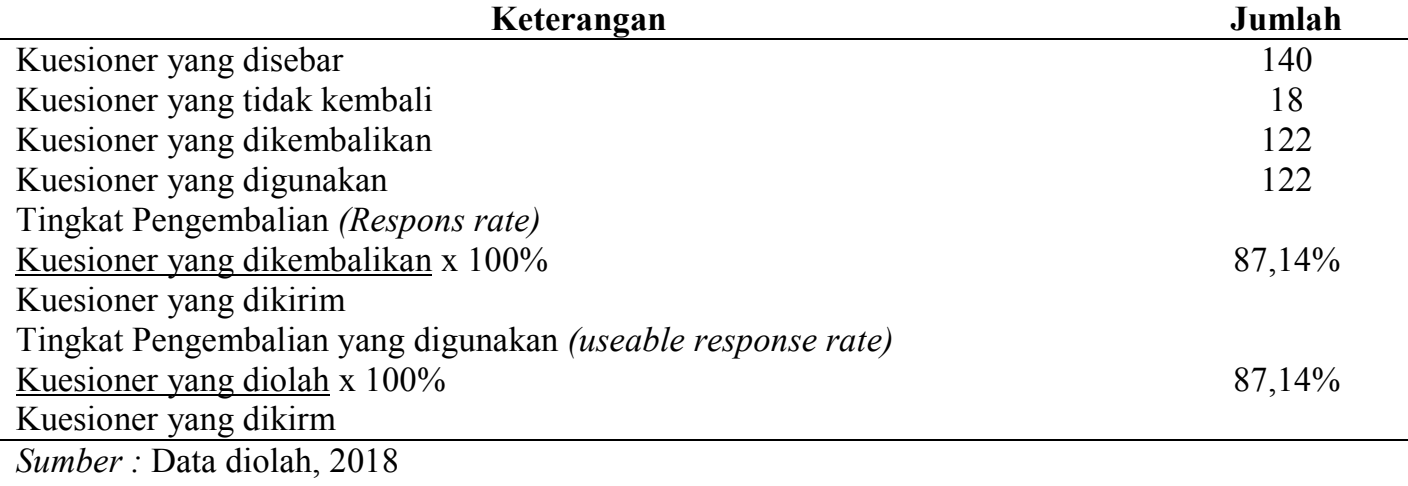

Berdasarkan Tabel 4. dapat dijelaskan bahwa kuesioner yang disebar sebanyak 140 buah eksemplar dan sebanyak 18 kuisioner tidak kembali, sehingga tingkat pengembalian kuisioner dalam penelitian ini sebesar $87,14 \%$, dan total kuesioner yang digunakan sebanyak 122 buah. Karakteristik responden pada penelitian ini, dapat dilihat dari beberapa kriteria yaitu: jenis kelamin, umur, pendidikan terakhir, dan rata-rata pendapatan responden.

Hasil Tabel 5. menunjukkan bahwa konsumen yang menggunakan sepatu League di dominasi oleh laki-laki sebanyak (72,13 persen) yang sudah lulus jenjang pendidikan SMA/SMK (40,16 persen) dengan kisaran usia 17 sampai 29 (51,64 persen). Hal ini berarti bahwa lebih banyak responden laki-laki dibandingkan perempuan yang memiliki niat untuk membeli produk sepatu League di Kota Denpasar. Hal tersebut disebabkan karena sepatu League lebih dirancang untuk sepatu sport laki-laki dalam bidang running, basketball, 
soccer/futsal, badminton dan lifestyle, dimana terdapat kecenderungan bahwa responden laki-laki yang lebih banyak melakukan aktivitas olahraga tersebut, sehingga mayoritas yang memiliki niat membeli sepatu League adalah responden laki-laki. Berdasarkan hasil wawancara pada responden perempuan yang memiliki niat membeli sepatu League diperoleh keterangan bahwa mereka niat membeli sepatu League sebagai hadiah untuk kerabat laki-lakinya yang memiliki hobi berolahraga.

Tabel 5.

Karakteristik Responden Penelitian

\begin{tabular}{|c|c|c|c|}
\hline \multicolumn{2}{|r|}{ Kriteria } & Jumlah (orang) & Persentase (\%) \\
\hline \multirow{2}{*}{ Jenis Kelamin } & Laki-Laki & 88 & 72,13 \\
\hline & Perempuan & 34 & 27,87 \\
\hline \multirow{5}{*}{ Pendidikan } & Jumlah & 122 & 100 \\
\hline & SMA/SMK & 49 & 40,16 \\
\hline & Diploma & 26 & 21,31 \\
\hline & Sarjana & 37 & 30,33 \\
\hline & Pasca Sarjana & 10 & 8,20 \\
\hline \multicolumn{2}{|r|}{ Jumlah } & 122 & 100 \\
\hline \multirow{5}{*}{ Umur } & $17-29$ Tahun & 63 & 51,64 \\
\hline & $30-39$ Tahun & 40 & 32,79 \\
\hline & 40 - 49 Tahun & 12 & 9,84 \\
\hline & $\geq 50$ Tahun & 7 & 5,74 \\
\hline & Jumlah & 122 & 100 \\
\hline \multirow{4}{*}{ Pekerjaan } & PNS & 28 & 22,95 \\
\hline & Pegawai Swasta & 31 & 25,41 \\
\hline & Wiraswasta & 20 & 16,39 \\
\hline & Mahasiswa & 43 & 35,25 \\
\hline \multirow{5}{*}{ Pendapatan } & Jumlah & 122 & 100 \\
\hline & Rp.2.000.000 - Rp.3.000.000 & 58 & 47,54 \\
\hline & Rp. 3.000.001 - Rp.5.000.000 & 47 & 38,52 \\
\hline & $>$ Rp. 5.000 .000 & 17 & 13,93 \\
\hline & Jumlah & 122 & 100 \\
\hline
\end{tabular}

Sumber: Data diolah, 2018

Hasil juga menunjukan bahwa konsumen yang memiliki niat beli pada produk sepatu League di kota Denpasar di dominasi oleh pelajar/mahasiswa dengan jumlah sebanyak 43 orang atau 35,25 persen. Dimana pada masa ini responden masih aktif dalam kegiatan olahraga, sehingga lebih banyak mahasiswa atau pelajar yang memiliki niat beli pada sepatu League. Apabila ditinjau berdasarkan tingkat pendapatan yang dimiliki, menunjukan bahwa responden yang memiliki niat beli pada produk sepatu League di kota Denpasar sebagian besar sudah bekerja dan memiliki pendapatan berkisar Rp. 2.000 .000 - Rp. 3.000.000 (47,54 persen) sehingga mampu untuk melakukan pembelian produk sepatu League tersebut.

Suatu instrumen dalam penelitian dikatakan valid apabila mampu mengukur apa yang ingin diukur. Suatu instrumen dikatakan valid apabila memiliki koefisien korelasi antara butir dengan skor total dalam instrumen tersebut lebih besar dari 0,30 dengan tingkat kesalahan Alpha 0,05. Hasil uji validitas pada Tabel 6 menunjukkan bahwa seluruh instrumen penelitian yang digunakan untuk 
mengukur variabel sikap, norma subyektif dan niat beli memiliki nilai koefisien korelasi dengan skor total seluruh item pernyataan lebih besar dari 0,30 dengan signifikansi kurang dari 0,05 . Hal ini menunjukkan bahwa butir-butir pernyataan dalam instrument penelitian tersebut valid dan layak digunakan sebagai instrument penelitian.

Tabel 6.

Rekapitulasi Hasil Uji Validitas Instrumen Penelitian

\begin{tabular}{|c|c|c|c|c|c|}
\hline No & Variabel & $\begin{array}{c}\text { Item } \\
\text { Pernyataan }\end{array}$ & Korelasi Item & Sig. (2-tailed) & Keterangan \\
\hline \multirow{5}{*}{1} & \multirow{5}{*}{$\begin{array}{l}\text { Sikap } \\
\left(\mathrm{X}_{1}\right)\end{array}$} & $\mathrm{X}_{1.1}$ & 0,737 & 0,000 & Valid \\
\hline & & $\mathrm{X}_{1.2}$ & 0,638 & 0,000 & Valid \\
\hline & & $\mathrm{X}_{1.3}$ & 0,693 & 0,000 & Valid \\
\hline & & $\mathrm{X}_{1.4}$ & 0,651 & 0,000 & Valid \\
\hline & & $\mathrm{X}_{1.5}$ & 0,367 & 0,000 & Valid \\
\hline \multirow{5}{*}{2} & \multirow{5}{*}{$\begin{array}{l}\text { Norma } \\
\text { Subyektif } \\
\quad\left(\mathrm{X}_{1}\right)\end{array}$} & $\mathrm{X}_{2.1}$ & 0,730 & 0,000 & Valid \\
\hline & & $\mathrm{X}_{2.2}$ & 0,590 & 0,000 & Valid \\
\hline & & $\mathrm{X}_{2.3}$ & 0,714 & 0,000 & Valid \\
\hline & & $\mathrm{X}_{2.4}$ & 0,746 & 0,000 & Valid \\
\hline & & $\mathrm{X}_{2.5}$ & 0,471 & 0,000 & Valid \\
\hline \multirow{4}{*}{3} & \multirow{4}{*}{$\begin{array}{l}\text { Niat Beli } \\
\left(\mathrm{X}_{1}\right)\end{array}$} & $\mathrm{Y}_{1}$ & 0,678 & 0,000 & Valid \\
\hline & & $\mathrm{Y}_{2}$ & 0,743 & 0,000 & Valid \\
\hline & & $\mathrm{Y}_{3}$ & 0,777 & 0,000 & Valid \\
\hline & & $\mathrm{Y}_{4}$ & 0,346 & 0,000 & Valid \\
\hline
\end{tabular}

Sumber: Data diolah, 2018

Uji Reliabilitas terhadap instrumen penelitian ini menggunakan nilai Alpha Cronbach, yakni untuk mengetahui unidimensionalitas butir-butir pernyataan terhadap variabel laten yang diteliti (sikap, norma subyektif dan niat beli). Nilai Alpha Cronbach dinyatakan reliabel jika nilainya lebih besar atau sama dengan 0,60 . Rekapitulasi hasil uji reliabilitas instrumen penelitian dapat dilihat pada Tabel 7 berikut.

Hasil uji reliabilitas yang disajikan dalam Tabel 7 menunjukkan bahwa seluruh instrumen penelitian memiliki koefisien Cronbach's Alpha lebih dari 0,60. Jadi dapat dinyatakan bahwa seluruh variabel telah memenuhi syarat reliabilitas atau kehandalan sehingga dapat digunakan untuk melakukan penelitian

Tabel 7.

Rekapitulasi Hasil Uji Reliabilitas Instrumen Penelitian

\begin{tabular}{clcc}
\hline No. & \multicolumn{1}{c}{ Variabel } & Cronbach's Alpha & Keterangan \\
\hline $\mathbf{1}$ & Sikap $\left(\mathrm{X}_{1}\right)$ & 0,742 & Reliabel \\
$\mathbf{2}$ & Norma Subyektif $\left(\mathrm{X}_{2}\right)$ & 0,756 & Reliabel \\
$\mathbf{3}$ & Niat Beli $(\mathrm{Y})$ & 0,748 & Reliabel \\
\hline
\end{tabular}


Pengumpulan data melalui kuesioner terdiri atas pernyataan responden berdasarkan masing-masing variabel, yaitu: variabel sikap, norma subyektif dan niat beli. Penilaian responden mengenai variabel-variabel dalam penelitian perlu dilakukan penentuan distribusi frekuensi berdasarkan nilai intervalnya, adapun untuk menentukan nilai interval yang dimaksud adalah sebagai berikut.

$$
\text { Interval }=\frac{\text { Nilai Tertinggi }- \text { Nilai Terendah }}{\text { Jumlah Kelas }}=\frac{5-1}{5}=0,80
$$

Skor pada penelitian ini memiliki nilai tertinggi maksimal 5 dan terendah minimal 1, sehingga dapat disusun kriteria pengukuran sebagai berikut.

Tabel 8.

Kriteria Pengukuran Deskripsi Variabel Penelitian

\begin{tabular}{ccccc}
\hline No. & Skala & Sikap & Norma subyektif & Niat beli \\
\hline 1 & $1,00-1,79$ & Sangat Tidak Baik & Sangat Tidak Baik & Sangat Rendah \\
2 & $1,80-2,59$ & Tidak Baik & Tidak Baik & Rendah \\
3 & $2,60-3,39$ & Kurang Baik & Kurang Baik & Sedang \\
4 & $3,40-4,19$ & Baik & Baik & Tinggi \\
5 & $4,20-5,00$ & Sangat Baik & Sangat Baik & Sangat Tinggi \\
\hline
\end{tabular}

Variabel sikap dalam penelitian ini merupakan variabel bebas yang diukur dengan menggunakan 5 pernyataan yang berhubungan dengan sikap konsumen pada produk sepatu League. Hasil penyebaran kuisioner pada Tabel 9 menunjukan secara keseluruhan rata-rata jawaban responden memiliki nilai sebesar 3,97. Hal ini menunjukkan bahwa responden sudah memiliki sikap yang baik pada produk sepatu League. Nilai rata-rata tertinggi terdapat pada pernyataan "Saya yakin produk Sepatu League memiliki kualitas yang baik" dengan nilai rata-rata 4,15.

Hal ini menunjukan bahwa secara keseluruhan responden yakin pada produk Sepatu League karena sudah memiliki kualitas yang baik. Nilai rata-rata terendah terdapat pada pernyataan "Saya yakin produk Sepatu League memiliki banyak pilihan warna", dengan nilai rata-rata sebesar 3,72. Hal ini menunjukkan bahwa masih terdapat beberapa responden yang menilai produk Sepatu League belum memiliki banyak pilihan warna. Oleh karena tidak semua konsumen mengetahui bahwa produk Sepatu League memiliki banyak pilihan warna, maka pihak marketing produk Sepatu League khususnya pada gerai produk League di Kota Denpasar menawarkan berbagai pilihan warna sepatu sesuai dengan warna yang diinginkan konsumen. Secara rinci hasil penelitian mengenai jawaban responden terhadap variabel sikap disajikan pada Tabel 9. 
Tabel 9.

Deskripsi Jawaban Responden Terhadap Variabel Sikap

\begin{tabular}{|c|c|c|c|c|c|c|c|c|}
\hline \multirow{2}{*}{ No } & \multirow{2}{*}{ Pernyataan } & \multicolumn{5}{|c|}{ Frekuensi Jawaban Responden } & \multirow{2}{*}{$\begin{array}{l}\text { Rata- } \\
\text { Rata }\end{array}$} & \multirow{2}{*}{ Kriteria } \\
\hline & & STS & TS & $\mathbf{N}$ & $\mathbf{S}$ & SS & & \\
\hline 1 & $\begin{array}{l}\text { Saya yakin produk Sepatu } \\
\text { League merupakan salah satu } \\
\text { brand yang terkenal. }\end{array}$ & 0 & 7 & 21 & 55 & 39 & 4,03 & Baik \\
\hline 2 & $\begin{array}{l}\text { Saya yakin produk Sepatu } \\
\text { League sudah memberi harga } \\
\text { yang terjangkau. } \\
\text { Saya yakin produk Sepatu }\end{array}$ & 0 & 7 & 15 & 63 & 37 & 4,07 & Baik \\
\hline 3 & $\begin{array}{l}\text { League mempunyai desain yang } \\
\text { elegan dan mewah. } \\
\text { Saya yakin produk Sepatu }\end{array}$ & 0 & 5 & 24 & 68 & 25 & 3,93 & Baik \\
\hline 4 & $\begin{array}{l}\text { League memiliki kualitas yang } \\
\text { baik. } \\
\text { Saya yakin produk Sepatu }\end{array}$ & 1 & 4 & 14 & 60 & 43 & 4,15 & Baik \\
\hline 5 & $\begin{array}{l}\text { League memiliki banyak pilihan } \\
\text { warna. }\end{array}$ & 0 & 8 & 38 & 56 & 20 & 3,72 & Baik \\
\hline & Rata-rata keselurul & an var & el Si & & & & 3,97 & Baik \\
\hline
\end{tabular}

Sumber: Data diolah, 2018

Variabel norma subyektif dalam penelitian ini merupakan variabel bebas yang diukur dengan menggunakan 5 pernyataan yang berhubungan dengan norma subyektif responden pada produk sepatu League. Secara rinci hasil penelitian mengenai persepsi responden terhadap variabel Norma subyektif disajikan pada Tabel 10. berikut.

Tabel 10. menunjukkan secara keseluruhan rata-rata jawaban responden terhadap variabel norma subyektif memiliki nilai sebesar 3,96. Hal ini berarti bahwa keputusan yang dibuat oleh konsumen setelah mempertimbangkan pandangan orang lain (referen) dalam membeli Produk Sepatu League sudah baik. Nilai rata-rata tertinggi pada variabel norma subjektif terdapat pada pernyataan "Teman dan kerabat menganjurkan untuk membeli produk sepatu merek League" dengan nilai rata-rata 4,16 . Hal ini menunjukan bahwa secara keseluruhan teman dan kerabat responden menganjurkan untuk membeli produk sepatu merek League, sehingga responden memiliki niat yang tinggi untuk membeli produk sepatu League.

Nilai rata-rata terendah pada variabel norma subjektif terdapat pada pernyataan "Saya menuruti pendapat teman dekat/sahabat dalam hal pembelian produk sepatu merek League", dengan nilai rata-rata sebesar 3,87. Hal ini menunjukan bahwa tidak semua responden menuruti pendapat teman dekat/sahabat dalam hal pembelian produk sepatu merek League yang disebabkan karena memiliki selera yang berbeda dengan teman dekat/sahabatnya tersebut. Oleh karena itu, pihak marketing produk Sepatu League dapat membuat produk yang sesuai selera dan tren yang sedang berkembang diantara konsumen di Kota Denpasar, sehingga norma subjektif konsumen semakin meningkat dan pada akhirnya dapat meningkatkan niat beli konsumen tersebut. Variabel niat beli dalam penelitian ini merupakan variabel terikat yang diukur dengan menggunakan 4 pernyataan yang berhubungan dengan niat beli produk sepatu League. 
Tabel 10.

Deskripsi Jawaban Responden Pada Variabel Norma subyektif

\begin{tabular}{|c|c|c|c|c|c|c|c|c|}
\hline \multirow{2}{*}{ No } & \multirow{2}{*}{ Pernyataan } & \multicolumn{5}{|c|}{ Frekuensi Jawaban Responden } & \multirow{2}{*}{$\begin{array}{l}\text { Rata- } \\
\text { Rata }\end{array}$} & \multirow{2}{*}{ Kriteria } \\
\hline & & STS & TS & $\mathbf{N}$ & $\mathbf{S}$ & SS & & \\
\hline 1 & $\begin{array}{l}\text { Anggota keluarga menyetujui } \\
\text { pembelian produk sepatu merek } \\
\text { League }\end{array}$ & 0 & 3 & 27 & 62 & 30 & 3,98 & Baik \\
\hline 2 & $\begin{array}{l}\text { Saya menuruti pendapat teman } \\
\text { dekat/sahabat dalam hal } \\
\text { pembelian produk sepatu merek } \\
\text { League }\end{array}$ & 0 & 7 & 22 & 73 & 20 & 3,87 & Baik \\
\hline 3 & $\begin{array}{l}\text { Teman dan kerabat memberi } \\
\text { tanggapan yang baik pada } \\
\text { produk sepatu merek League }\end{array}$ & 0 & 5 & 25 & 66 & 26 & 3,93 & Baik \\
\hline 4 & $\begin{array}{l}\text { Teman dan kerabat } \\
\text { menganjurkan untuk membeli } \\
\text { produk sepatu merek League }\end{array}$ & 0 & 6 & 10 & 65 & 41 & 4,16 & Baik \\
\hline 5 & $\begin{array}{llr}\text { Teman dan } & \text { kerabat } \\
\text { menggunakan produk } & \text { sepatu } \\
\text { merek League } & & \end{array}$ & 0 & 6 & 32 & 51 & 33 & 3,91 & Baik \\
\hline \multicolumn{7}{|c|}{ Rata-rata keseluruhan variabel Norma subyektif } & 3,96 & Baik \\
\hline
\end{tabular}

Sumber: Data diolah, 2018

Tabel 11. menunjukkan secara keseluruhan rata-rata jawaban responden terhadap variabel niat beli memiliki nilai sebesar 3,95. Hal ini berarti bahwa secara keseluruhan konsumen memiliki niat yang tinggi unutk membeli sepatu League. Nilai rata-rata tertinggi terdapat pada pernyataan "Saya memiliki keinginan untuk mencoba Produk Sepatu League" dengan nilai rata-rata 4,09. Hal ini menunjukan bahwa secara keseluruhan konsumen dalam penelitian ini memiliki keinginan untuk mencoba Produk Sepatu League.

Tabel 11.

Deskripsi Jawaban Responden Terhadap Variabel Niat beli

\begin{tabular}{|c|c|c|c|c|c|c|c|c|}
\hline \multirow[t]{2}{*}{ No } & \multirow[t]{2}{*}{ Pernyataan } & \multicolumn{5}{|c|}{$\begin{array}{c}\text { Frekuensi Jawaban } \\
\text { Responden } \\
\end{array}$} & \multirow{2}{*}{$\begin{array}{l}\text { Rata- } \\
\text { Rata }\end{array}$} & \multirow[t]{2}{*}{ Kriteria } \\
\hline & & STS & TS & $\mathbf{N}$ & $\mathbf{S}$ & SS & & \\
\hline 1 & $\begin{array}{l}\text { Saya mencari informasi tentang } \\
\text { produk Sepatu League. }\end{array}$ & 0 & 6 & 21 & 66 & 29 & 3,97 & Tinggi \\
\hline 2 & $\begin{array}{l}\text { Saya membicarakan Produk } \\
\text { Sepatu League dengan teman. }\end{array}$ & 0 & 9 & 24 & 68 & 21 & 3,83 & Tinggi \\
\hline 3 & $\begin{array}{l}\text { Saya memiliki keinginan untuk } \\
\text { mencoba Produk Sepatu League. }\end{array}$ & 0 & 8 & 15 & 57 & 42 & 4,09 & Tinggi \\
\hline 4 & $\begin{array}{l}\text { Saya berniat untuk membeli } \\
\text { Produk Sepatu League. }\end{array}$ & 0 & 3 & 30 & 62 & 27 & 3,93 & Tinggi \\
\hline \multicolumn{7}{|c|}{ Rata-rata keseluruhan variabel Niat beli } & 3,95 & Tinggi \\
\hline
\end{tabular}

Sumber: Data diolah, 2018

Nilai rata-rata terendah pada variabel niat beli terdapat pada pernyataan "Saya membicarakan Produk Sepatu League dengan teman", dengan nilai rata-rata 
sebesar 3,83. Hal ini menunjukkan bahwa masih ada konsumen yang tidak membicarakan Produk Sepatu League dengan teman. Hal ini bisa saja disebabkan karena konsumen secara langsung mencari informasi melalui internet mengenai produk sepatu League. Oleh karena itu, pihak marketing produk Sepatu League sebaiknya membuat informasi yang lengkap mengenai keterangan dan keunggulan dari produk sepatu League secara rinci di internet, agar niat beli konsumen akan semakin meningkat.

Model regresi akan lebih tepat digunakan dan menghasilkan perhitungan yang lebih akurat, apabila beberapa asumsi berikut dapat terpenuhi. Uji asumsi klasik yang harus dipenuhi pada analisis regresi linear berganda antara lain Uji Normalitas, Uji Multikolenearitas dan Uji Heterokedastisitas. Hasil uji asumsi klasik pada penelitian ini dirangkum dalam Tabel 12 berikut.

Tabel 12.

Rangkuman Hasil Uji Asumsi Klasik

\begin{tabular}{|c|c|c|c|c|c|}
\hline \multirow{2}{*}{\multicolumn{2}{|c|}{ Hasil Uji Normalitas }} & \multirow[t]{2}{*}{ Variabel } & \multicolumn{2}{|c|}{$\begin{array}{c}\text { Hasil Uji } \\
\text { Multikolinieritas }\end{array}$} & \multirow{2}{*}{$\begin{array}{c}\text { Hasil Uji } \\
\text { Heteroskedastisitas } \\
\text { Signifikansi }\end{array}$} \\
\hline & & & Tolerance & VIF & \\
\hline $\begin{array}{l}\text { Kolmogorov- } \\
\text { Smirnov } Z\end{array}$ & 0,689 & Sikap $\left(\mathrm{X}_{1}\right)$ & 0,783 & 1,277 & 0,794 \\
\hline $\begin{array}{l}\text { Asymp.Sig. (2- } \\
\text { tailed) }\end{array}$ & 0,729 & $\begin{array}{l}\text { Norma } \\
\text { subjektif }\left(\mathrm{X}_{2}\right)\end{array}$ & 0,783 & 1,277 & 0,609 \\
\hline
\end{tabular}

Sumber: Data diolah, 2018

Nilai signifikansi uji Kolmogorov-Smirnov lebih dari 0,05 maka dapat disimpulkan bahwa model persamaan regresi sudah berdistribusi normal. Kemudian nilai tolerance dan VIF untuk setiap variabel lebih besar dari $10 \%$ dan nilai VIF lebih kecil dari 10 yang berarti model persamaan regresi bebas dari multikolinearitas. Hasil juga menunjukkan nilai Signifikansi dari variabel sikap sebesar 0,794, dan norma subjektif sebesar 0,609. Nilai tersebut lebih besar dari 0,05 yang berarti tidak terdapat pengaruh antara variabel bebas terhadap absolute residual, maka model yang dibuat tidak mengandung gejala heteroskedastisitas. Oleh karena itu, dapat disimpulkan bahwa semua uji asumsi klasik sudah terpenuhi sehingga hasil analisis regresi layak untuk dibahas lebih lanjut.

Tabel 13.

Hasil Analisis Regresi Linier Berganda

\begin{tabular}{|c|c|c|c|c|c|}
\hline \multirow[t]{2}{*}{ Model } & \multicolumn{2}{|c|}{$\begin{array}{c}\text { Unstandardized } \\
\text { Coefficients }\end{array}$} & \multirow{2}{*}{$\begin{array}{c}\begin{array}{c}\text { Standardized } \\
\text { Coefficients }\end{array} \\
\text { Beta } \\
\end{array}$} & \multirow[b]{2}{*}{$\mathbf{T}$} & \multirow[b]{2}{*}{ Sig. } \\
\hline & B & Std. Error & & & \\
\hline $1 \quad$ (Constant) & 4.565 & 1.404 & & 3.252 & .001 \\
\hline Sikap & .235 & .068 & .286 & 3.444 & .001 \\
\hline Norma Subyektif & .331 & .068 & .407 & 4.896 & .000 \\
\hline
\end{tabular}

Sumber: Data diolah, 2018

Berdasarkan hasil analisis regresi linier berganda seperti yang disajikan pada Tabel 13, maka dapat dibuat persamaan regresi sebagai berikut:

$$
\mathrm{Y}=4,565+0,235 \mathrm{X}_{1}+0,331 \mathrm{X}_{2}
$$


Nilai koefisien regresi masing-masing variabel bebas bernilai positif dengan nilai signifikansi uji t kurang dari 0,05 . Hal ini menunjukkan bahwa semua variabel bebas memiliki pengaruh positif yang signifikan terhadap variabel terikat.

Tabel 14.

Hasil Uji Koefisien Determinasi

\begin{tabular}{crrrr}
\hline Model & R & R Square & Adjusted R Square & $\begin{array}{c}\text { Std. Error of the } \\
\text { Estimate }\end{array}$ \\
\hline 1 & $.597^{\mathrm{a}}$ & .356 & .345 & 1.656 \\
\hline
\end{tabular}

Sumber: Data diolah, 2018

Hasil uji pada Tabel 14. memberikan hasil dimana diperoleh besarnya adjusted $\mathrm{R}^{2}$ (koefisien determinasi yang telah disesuaikan) adalah sebesar 0,345. Ini berarti variasi niat beli produk sepatu League di kota Denpasar dapat dipengaruhi secara signifikan oleh variabel sikap dan norma subjektif sebesar 34,5 persen, sedangkan sisanya sebesar 65,5 persen dijelaskan oleh faktor lain yang tidak dijelaskan dalam model penelitian.

Berdasarkan hasil analisis pengaruh sikap terhadap niat beli pada tabel 13 diperoleh nilai signifikasi sebesar 0,001 dengan nilai koefisien beta 0,235 . Nilai Signifikansi $0,001<0,05$ mengindikasikan bahwa $\mathrm{H}_{0}$ ditolak dan $\mathrm{H}_{1}$ diterima. Hasil ini mempunyai arti bahwa Sikap berpengaruh positif dan signifikan terhadap Niat beli produk sepatu League di kota Denpasar, maka semakin tinggi niat beli konsumen pada produk produk sepatu League di Kota Denpasar. Begitu pula sebaliknya, semakin buruk sikap konsumen pada produk sepatu League, maka semakin rendah niat beli konsumen pada produk sepatu League di Kota Denpasar.

Hasil tersebut mengindikasikan bahwa nilai - nilai yang terkandung dalam sikap mampu dipersepsikan dengan baik dan berdampak nyata terhadap niat beli produk sepatu League di Kota Denpasar. Sikap yang diukur berdasarkan indikator: merek produk, harga produk, desain produk, kualitas produk dan pilihan produk terbukti mampu meningkatkan niat beli konsumen pada produk Sepatu League di Kota Denpasar. Temuan ini dapat diartikan bahwa apabila sikap positif oleh seluruh konsumen dapat ditingkatkan, maka akan mampu memberikan kontribusi yang signifikan untuk meningkatkan niat beli konsumen pada produk sepatu League di Kota Denpasar.

Penelitian ini mendukung beberapa hasil penelitian sebelumnya dan konsisten dengan hasil penelitian Pradnyana \& Sukawati (2016) yang menyatakan bahwa terdapat pengaruh positif signifikan antara Sikap terhadap Niat Beli. Hal tersebut berarti bahwa semakin baik sikap konsumen, maka niat beli konsumen pada produk tersebut akan meningkat. Penelitian serupa yang dilakukan Sigit (2006), Eriyani \& Wiyono (2012), Mandasari \& Nurcaya (2013), Pradipta \& Suprapti (2013) serta Marhaini (2008) juga menemukan hasil bahwa variabel sikap berpengaruh positif dan signifikan terhadap niat beli produk.

Berdasarkan hasil analisis pengaruh norma subjektif terhadap niat beli pada Tabel 13 diperoleh nilai signifikansi sebesar 0,000 dengan nilai koefisien beta 0,331. Nilai Signifikansi $0,000<0,05$ mengindikasikan bahwa $\mathrm{H}_{0}$ ditolak dan $\mathrm{H}_{2}$ diterima. Hasil ini mempunyai arti bahwa norma subjektif berpengaruh positif dan signifikan terhadap niat beli produk sepatu League di kota Denpasar. Hal ini 
memiliki makna bahwa semakin baik norma subjektif pada produk sepatu League, maka semakin tinggi niat konsumen untuk membeli produk sepatu League di Kota Denpasar. Begitu pula sebaliknya, semakin buruk norma subjektif pada produk sepatu League, maka semakin rendah niat konsumen untuk membeli produk sepatu League di Kota Denpasar.

Hasil tersebut mengindikasikan bahwa nilai - nilai yang terkandung dalam norma subjektif mampu dipersepsikan dengan baik dan berdampak nyata terhadap niat beli produk sepatu League di Kota Denpasar. Norma subjektif yang diukur berdasarkan indikator: keyakinan terhadap pendapatan orang lain, motivasi untuk menuruti pengaruh orang lain, pandangan teman dan kerabat, ajakan dari teman dan kerabat, serta rekomendasi dari teman dan kerabat terbukti mampu meningkatkan niat beli produk sepatu League di Kota Denpasar. Temuan ini dapat diartikan bahwa apabila konsumen memperoleh pandangan orang lain (referen) dalam membeli Produk Sepatu League secara positif, maka akan mampu memberikan kontribusi yang signifikan terhadap meningkatnya niat beli konsumen pada produk sepatu League di Kota Denpasar.

Penelitian ini mendukung beberapa hasil penelitian sebelumnya dan konsisten dengan hasil penelitian Sigit (2006) yang menunjukan hasil bahwa norma subyektif berpengaruh positif terhadap niat beli. Penelitian serupa yang dilakukan oleh Pradipta \& Suprapti (2013) dan Mandasari \& Nurcaya (2013) juga memperoleh hasil bahwa norma subjektif berpengaruh positif dan signifikan terhadap niat beli produk hijau. Hal ini menunjukkan bahwa semakin tinggi norma subjektif pada Produk Sepatu League maka minat konsumen dalam membeli produk sepatu League di Kota Denpasar akan semakin meningkat.

Penelitian yang dilakukan dapat memberikan kontribusi mengenai pengaruh sikap dan norma subyektif terhadap niat beli pada produk sepatu League di Kota Denpasar. Hasil uji hipotesis dalam penelitian ini ditemukan bahwa seluruh variabel bebas yang terdiri dari sikap $\left(\mathrm{X}_{1}\right)$, dan norma subyektif $\left(\mathrm{X}_{2}\right)$ secara statistik berpengaruh positif pada niat beli produk sepatu League di Kota Denpasar, sehingga variabel tersebut dapat dipertahankan sebagai variabel bebas untuk penelitian selanjutnya.

Penelitian ini memberikan implikasi bagi pihak marketing produk sepatu League di Kota Denpasar sebagai bahan pertimbangan dan evaluasi mengenai niat beli serta faktor-faktor yang memengaruhinya. Pihak marketing produk sepatu League di Kota Denpasar dalam meningkatkan niat beli konsumen sebaiknya dapat melihat dan mempertimbangkan faktor sikap dan norma subjektif, karena hal tersebut dapat mempengaruhi niat beli produk sepatu League di kota Denpasar.

\section{SIMPULAN}

Berdasarkan hasil analisis penelitian dan hasil pembahasan maka simpulan dari penelitian ini yaitu pertama, sikap berpengaruh positif dan signifikan terhadap niat beli produk sepatu League di kota Denpasar. Hal ini memiliki makna bahwa semakin positif sikap konsumen pada produk sepatu League, maka semakin tinggi niat beli konsumen pada produk sepatu League di Kota Denpasar. Kedua, Norma subjektif berpengaruh positif dan signifikan terhadap niat beli produk sepatu 
League di Kota Denpasar. Hal ini memiliki makna bahwa semakin baik norma subjektif pada produk sepatu League, maka semakin tinggi niat konsumen untuk membeli produk sepatu League di Kota Denpasar.

Saran yang diberikan agar dapat dipergunakan sebagai bahan pertimbangan dalam menentukan kebijakan untuk meningkatkan niat beli produk sepatu League di Kota Denpasar pada masa mendatang yaitu sebaiknya pihak marketing produk Sepatu League khususnya pada gerai produk League di Kota Denpasar menawarkan berbagai pilihan warna sepatu sesuai dengan warna yang diinginkan konsumen. Kemudian pihak marketing produk Sepatu League juga disarankan untuk dapat membuat produk yang sesuai selera dan tren yang sedang berkembang diantara konsumen di Kota Denpasar, sehingga norma subjektif konsumen semakin meningkat dan pada akhirnya dapat meningkatkan niat beli konsumen tersebut.

\section{REFERENSI}

Ajzen, I. (2008). The Theory Of Planned Behavior, Organizational Behavior And Human Decisio Processes, 50, 179-211.

Anidia, A. (2016). Analisis Pengaruh Sikap, Norma Subyektif, Dan Kontrol Perilaku Yang Dirasakan Terhadap Minat Beli Produk Private Brand Alfamart di Sekitar Universitas Muhammadiyah Surakarta. Universitas Muhammadiyah Surakarta.

Azwar, S. (2012). Penyusunan Skala Psikologi. (P. Pelajar, Ed.) (2nd ed.). Yogyakarta.

Chekima, B., Wafa, S. A. W. S. K., Igau, O. A., \& Chekima, S. (2015). Determinant factors of consumers' green purchase intention: The moderating role of environmental advertising. Asian Social Scienc, 11(10), 318-329. https://doi.org/10.5539/ass.v11n10p318

Crespo, A. H., \& Rodríguez, I. R. (2010). Explaining B2C e-commerce acceptance: An integrative model based on the framework by Gatignon and Robertson. Interacting with Computers, 20(2), 212-224. https://doi.org/10.1016/j.intcom.2007.11.005

Eriyani, \& Wiyono. (2012). Pengaruh Sikap, Persepsi Kontrol Perilaku, Dan Norma Subjektif Pada Niat Beli Kosmetik Organik: Studi Pada Mahasiswa Universitas Sebelas Maret Surakarta. Fokus Manajerial, 11(2), 140-154.

Ferdinand, A. (2006). Metode Penelitian Manajemen: Pedoman Penelitian untuk Skripsi, Thesis, dan Disertasi Ilmu Manajemen. Semarang: BP UNDIP.

Hartini, S. (2012). Perilaku Pembelian Smartphone: Analisis Brand Equity Dan Brand Attachment. Jurnal Mitra Ekonomi Dan Manajemen Bisnis, 3(1), 75 86.

James, M. S., \& Christodoulidou, N. (2011). Factor Influencing Wine Consumtion in Southern California Consumers. International Journal of Wine Business Research, 23(1), 36-48. https://doi.org/10.1108/17511061111121399

Kotler, P., \& Armstrong, G. (2008). Prinsip-prinsip Pemasaran (1st ed.). Jakarta: Erlangga.

Laili. (2010). Pengaruh Sikap, Norma Subjektif dan Kontrol Keperilakuan Terhadap Niat Beli dan Perilaku beli Produk Susu Ultra High Temperature. 
Jurnal Fakultas Peternakan Universitas Gajahmada, 507-512.

Mada, Y. P. (2016). Analisis Pengaruh Sikap terhadap Perilaku, Norma Subjektif dan Kontrol Kepemilikan yang Dirasakan terhadap Niat dan Perilaku Konsumen. Infestasi, 1(1), 79-88.

Mandasari, R. N. P. N., \& Nurcaya, I. N. (2013). Pengaruh Sikap Konsumen Dan Norma Subjektif Terhadap Niat Beli Mobil Toyota Agya Di Kota Denpasar. E-Jurnal Manajemen Universitas Udayana, 2(11), 2302-8912. Retrieved from https://ojs.unud.ac.id/index.php/Manajemen/article/view/5829

Marhaini. (2008). Analisis Prilaku Konsumen dalam Pembelian Komputer Merek Acer (Studi Kasus: Mahasiswa Fakultas Ekonomi Universitas Sumatra Utara). Jurnal Manajemen Bisnis, 1(3), 89-96.

Moon, S., Ryu, M., \& Lee, R. (2015). The Effect of Value, Motivations, Attitude, Subjective norm on the Envirronmental Friendly Product Purchase Intention. Journal of School of Business Kyungpok National University, 22(1), 131134.

Mowen, J., \& Minor, M. (2007). Perilaku Konsumen. Jakarta: Erlangga.

Nurdiansyah, D. (2017). Pengaruh Kualitas Produk Dan Harga Terhadap Keputusan Pembelian Produk Sepatu Olahraga Merek Adidas Di Bandar Lampung. Universitas Lampung.

Paul, P. J., \& Olson, J. C. (2000). Consumer Behaviour: Perilaku Konsumen dan Strategi Pemasaran (1st ed.). Jakarta: Erlangga.

Pradipta, I. G. S., \& Suprapti, N. W. S. (2013). Pengaruh Sikap dan Norma Subjektif Terhadap Niat Calon Pemilih di Kota Denpasar Untuk Memilih Partai Demokrat Dalam Pemilu Legislatif Tahun 2014. Jurnal Manajemen, Strategi Bisnis, Dan Kewirausahaan, 7(1), 29-39.

Pradnyana, I. W. B., \& Sukawati, T. G. R. (2016). Pengaruh Sikap Dan Norma Subjektif Terhadap Niat KOnsumen Membeli Sepeda Motor Honda Vario Techno 125 CBS. E-Jurnal Manajemen Unud, 5(9), 5462-5493.

Sigit, M. (2006). Pengaruh Sikap dan Norma Subjektif Terhadap Niat Beli Mahasiswa Sebagai Konsumen Potensial Produk Pasta Gigi Close Up. Jurnal Siasat Bisnis, 11(1), 81-91.

Silitonga, L. T. (2018). PASAR SEPATU: Ini Dia Merek yang Jadi Raja Pasar. Bisnis.Com. Retrieved from https://ekonomi.bisnis.com/read/20180207/12/735561/pasar-sepatu-ini-diamerek-yang-jadi-raja-pasar

Simamora, B. (2015). Panduan Riset Perilaku Konsumen. Jakarta: PT Gramedia Pustaka Utama.

Sugiyono. (2013). Metode Penelitian Kuantitatif, Kualitatif Dan Kombinasi (Mixed Methods). Bandung: Alfabeta.

Sumarwan, U. (2011). Perilaku Konsumen Pemahaman Dasar dan Aplikasinya Dalam Strategi Pemasaran. Denpasar: Udayana University Press.

Suprapti, N. W. S. (2010). Prilaku Konsumen, Pemahaman Dasar dan Aplikasinya Dalam Strategi Pemasaran. Denpasar: Udayana University Press.

Umar, H. (2013). Metode Penelitian untuk Skripsi dan Tesis. Jakarta: Rajawali Press. 
I Kadek Alit Suarjana, Pengaruh Sikap dan ...

Wen, L.-Y. M., \& Li, S.-H. (2013). A Study On The Relationship Amidst Health Consciousness, Ecological Affect, And Purchase Intention Of Green Production. International Journal of Organizational Innovation, 5(4), 124137. 